\title{
PENGEMBANGAN MODUL PRAKTIKUM DILAN (DISCOVERY LEARNING) UNTUK PEMBELAJARAN SAINS DI KELAS V SEKOLAH DASAR
}

\author{
${ }^{1}$ Azizah \\ Universitas Darul Ulum Islamic Centre Sudirman \\ azizaathalib@gmail.com \\ ${ }^{2}$ Puji Winarti \\ Universitas Darul Ulum Islamic Centre Sudirman \\ pujiwinartirulian@gmail.com
}

\begin{abstract}
Abstrak
Penelitian ini bertujuan untuk mengembangkan Modul Praktikum Dilan (Discovery Learning) untuk pembelajaran Sains di Kelas V Sekolah Dasar yang telah memenuhi kriteria valid, praktis, dan efektif untuk digunakan dalam pembelajaran Sains di sekolah dasar. Jenis penelitian ini adalah penelitian dan pengembangan (Research \& Development) yang menggunakan model Borg and Gall. Jenis penelitian ini terdiri dari 9 langkah yaitu (1) studi pendahuluan, (2) perencanaan penelitian, (3) pengembangan produk awal, (4) uji lapangan terbatas, (5) revisi hasil uji lapangan terbatas, (6) uji lapangan lebih luas, (7) revisi hasil uji lapangan lebih luas, (8) uji kelayakan, (9) revisi hasil uji kelayakan. Hasil penelitian menunjukan bahwa Modul Praktikum Dilan (Discovery Learning) untuk pembelajaran Sains di Kelas V SD telah valid, praktis dan efektif. Nilai kevalidan yang diperoleh sebesar 61,5 dengan kriteria sangat valid. Nilai kepraktisan sebesar 66,27 atau sangat praktis. Serta perolehan nilai kefektifan sebesar 0,72 dengan kriteria sangat efektif. Dari hasil perolehan ini maka dapat disimpulkan bahwa Modul Praktikum Dilan (Discovery Learning) untuk pembelajaran Sains di Kelas V SD dapat digunakan dalam proses pembelajaran IPA karena telah memenuhi kriteria valid, praktis, dan efektif.
\end{abstract}

Kata Kunci: Modul Dilan, Discovery Learning, dan Pembelajaran IPA

\section{DEVELOPMENT OF DILAN (DISCOVERY LEARNING) PRACTICUM MODULE FOR SCIENCE LEARNING IN CLASS V ELEMENTARY SCHOOL}

\begin{abstract}
This study aims to develop a Dilan (Discovery Learning) Practicum Module for Science learning in Class $V$ Elementary Schools that has fulfilled valid, practical, and effective criteria for use in Science learning in elementary schools. This type of research is research and development that uses the Borg and Gall model. This type of research consists of 9 steps, namely (1) preliminary study, (2) research planning, (3) initial product development, (4) limited field testing, (5) limited revised field test results, (6) wider field test, (7) revisions to the results of broader field tests, (8) feasibility tests, (9) revisions to the results of due diligence. The results of the study show that the Dilan (Discovery Learning) Practicum Module for Science learning in Class V Elementary School has been valid, practical and effective. The validity value obtained is 61.5 with very valid criteria. Practical value of 66,27 or very practical. As well as the acquisition of effectiveness values of 0.72 with very effective criteria. From the results of this acquisition, it can be concluded that the Dilan (Discovery Learning) Practicum Module for Science learning in Class V Elementary School can be used in the science learning process because it has met valid, practical, and effective criteria.
\end{abstract}

Keywords: Module Dilan, Discovery Learning, and Science Learning 


\section{A. PENDAHULUAN}

Dalam rangka mewujudkan penyelenggaraan pendidikan seperti yang tertuang dalam Undang-undang Nomor 20 Tahun 2003 tentang Sistem Pendidikan Nasional, telah banyak cara yang dilakukan oleh pemerintah baik di pusat maupun di daerah-daerah. Seperti di Jawa Tengah, perwujudan pendidikan terlihat pada visi Dinas Pendidikan Provinsi Jawa Tengah yang termuat dalam Renstra Dinas Pendidikan Tahun 2013-2018 yaitu Pendidikan Jawa Tengah yang Bermutu, Kompetitif, Berkarakter, dan Berkeadilan. Makna visi tersebut adalah meningkatkan harkat dan martabat sumber daya manusia melalui pendidikan formal dan nonfomal di semua jenjang pendidikan yang menjangkau seluruh komponen masyarakat tanpa diskriminatif yang memenuhi standar isi, standar proses, standar kompetensi lulusan, standar sarpras, standar pembiayaan, standar pendidik dan tenaga kependidikan, standar penilaian dan standar pengelolaan sehingga menghasilkan manusia berkarakter dan terdidik yang berwawasan kebangsaan tanpa meninggalkan nilai luhur kearifan lokal mampu bersaing mampu bersaing di era persaingan global.

Salah satu misi untuk mewujudkan visi di atas di bidang pendidikan sekolah dasar yaitu meningkatkan layanan pendidikan dasar (DIKDAS) yang merata dan berkualitas dengan tujuan meningkatkan ketersediaan dan kualitas layanan Pendidikan Dasar. Adapun sasaran dari tujuan tersebut adalah meningkatnya sarana prasarana pendidikan yang berkualitas, pembinaan potensi siswa dan penerapan kurikulum yang merata. Beberapa program kegiatan yang akan dilakukan demi tercapainya tujuan tersebut antara lain kegiatan pengembangan kelembagaan pendidikan dasar, kegiatan pemenuhan sarana dan prasarana pendidikan dasar, kegiatan implementasi kurikulum pendidikan dasar, kegiatan pembinaan kesiswaan pendidikan dasar, dan kegiatan pengembangan dan pengayaan sumber belajar pendidikan dasar, (Pemprov, 2013).

Secara umum permasalahan dalam pembangunan pendidikan pada tahun 2012 adalah belum optimalnya ketersediaan, keterjangkauan, kualitas, kesetaraan dan kepastian dalam penyelenggaraan pendidikan. Permasalahan dalam bidang pendidikan dasar yaitu belum terpenuhinya standar sarana prasarana Pendidikan Dasar, belum optimalnya pelaksanaan Manajemen Berbasis Sekolah (MBS), belum optimalnya pembinaan kesiswaan, belum semua satuan pendidikan menerapkan kurikulum 2013, dan belum terpenuhinya standar nasional satuan pendidikan dasar. Data yang diperoleh pada Tahun 2012 khusus untuk sarana prasarana pendidikan dasar baru mencapai $63,14 \%$. Oleh karena itu, pemenuhan sarana dan prasarana pendidikan dasar menjadi salah satu tujuan dalam program kerja pemerintah Dinas Pendidikan Jawa Tengah pada Tahun 2013-2018, (Pemprov, 2013). 
Sarana pendidikan adalah peralatan dan perlengkapan yang secara langsung dipergunakan dan menunjang proses pendidikan, khususnya proses belajar mengajar, seperti gedung, ruang kelas, meja-kursi, buku, modul, serta alat-alat dan media pengajaran. Sedangkan prasarana pendidikan adalah fasilitas yang secara tidak langsung menunjang jalannya proses pendidikan atau pengajaran, seperti halaman, kebun, taman sekolah, jalan menuju sekolah, tetapi jika dimanfaatkan secara langsung untuk proses belajar, komponen tersebut merupakan sarana pendidikan, (Mulyasa, 2010:49). Manajemen sarana dan prasarana yang baik diharapkan dapat menciptakan sekolah yang bersih, rapi, indah sehingga menciptakan kondisi yang menyenangkan baik bagi guru maupun bagi peserta didik untuk berada di sekolah. Di samping itu juga diharapkan tersedianya alat-alat atau fasilitas belajar yang memadai secara kuantitatif, kualitatif, dan relevan dengan kebutuhan serta dapat dimanfaatkan secara optimal untuk kepentingan proses pendidikan dan pengajaran, baik oleh guru sebagai pengajar maupun peserta didik sebagai pelajar.

Kondisi ideal di atas ternyata tidak mudah dipenuhi baik oleh sekolah, guru, maupun siswa. Dalam proses belajar mengajar, fasilitas belajar seperti media pembelajaran masih kurang mendapat perhatian baik oleh sekolah maupun guru. Tidak adanya media pembelajaran dalam proses pembelajaran akan mempengaruhi perolehan hasil belajar oleh siswa. Penggunaan media pembelajaran mempunyai tujuan memberikan motivasi kepada peserta didik serta merangsang siswa mengingat apa yang sudah dipelajari selain memberikan rangsangan belajar baru. Media yang baik juga akan mengaktifkan siswa dalam memberikan tanggapan, umpan balik dan juga mendorong untuk melakukan praktek-praktek dengan benar.

Dari hasil observasi dan wawancara yang dilakukan dengan guru-guru di beberapa sekolah dasar Kabupaten Semarang seperti SDN Leyangan Kecamatan Ungaran Timur, SDN Gebugan 02 Kecamatan Bergas, MI Almina Kecamatan Bandungan, SDN Kecamatan Getasan, diperoleh bahwa kurangnya media pembelajaran seperti alat peraga dan modul praktikum dalam pelajaran IPA. Selama ini, guru-guru hanya mengandalkan buku paket dan LKS (Lembar Kerja Siswa) dalam pembelajaran IPA. Dalam proses pembelajaran, guru lebih banyak mendrill tanpa menanamkan konsep IPA kepada siswa. Lebih mengutamakan pencapaian hasil belajar kognitif, kurang menekankan pencapaian keterampilan proses sains. Pembelajaran IPA yang dilaksanakan secara konvensional tanpa atau dengan melakukan praktikum dengan materi yang terbatas menjadi tidak bermakna bagi siswa. Siswa menjadi tidak termotivasi, kreatif, kritis, peka terhadap lingkungan, dan memahami teknologi sederhana di tengah-tengah masyarakat sehingga beranggapan pembelajaran IPA sukar untuk 
dipahami. Minimnya kegiatan praktikum yang dilakukan oleh guru-guru tersebut dikarenakan oleh kurangnya alat peraga dan media pembelajaran IPA yang dimiliki oleh sekolah.

Secara menyeluruh sains atau Ilmu Pengetahuan Alam (IPA) menurut Collette \& Chiappetta (2014) diartikan sebagai cara menyelidiki (as a way of investigating) tentang fenomena alam, dan sebagai tubuh pengetahuan (as a body of knowledge) yang dihasilkan dari penyelidikan. Menurut Edward Teller, sains adalah studi tentang alam dalam upaya untuk memahaminya dan untuk menciptakan pengetahuan baru yang memberikan kemampuan untuk melakukan prediksi dan mengaplikasikannya. Ini tersirat dalam pernyataannya yaitu seorang ilmuan memiliki tiga tanggung jawab, pertama untuk dapat memahami, kedua untuk menjelaskan pemahaman tersebut dan ketiga adalah untuk menerapkan hasil dari pemahaman tersebut, (Collette \& Chiappetta, 1994)

Pengertian di atas sesuai dengan teori Bruner. Menurut Jerome Bruner, kegiatan belajar akan berjalan baik dan kreatif jika siswa dapat menemukan sendiri suatu aturan atau kesimpulan tertentu. Metode ini disebut metode belajar menemukan (discovery learning). Melalui discovery learning siswa dilatih untuk memecahkan masalah dan informasi yang diperolehnya serta akhirnya akan mendapatkan pengetahuan yang bermakna. Metode ini akan berjalan efektif jika dilengkapi dengan media pembelajaran IPA. Penggunaan media dalam pembelajaran akan menimbulkan komunikasi timbal balik antar siswa dan guru, mempertinggi kualitas proses belajar mengajar serta dapat mewujudkan tujuan pembelajaran IPA yang pada akhirnya diharapkan meningkatkan kualitas hasil belajar siswa.

Modul merupakan salah satu media pembelajaran yang dapat digunakan dalam pembelajaran IPA. Menurut Daryanto. (2013) modul adalah salah satu bentuk bahan ajar yang dikemas secara utuh dan sistematis, di dalamnya memuat seperangkat pengalaman belajar yang terencana dan didesain untuk membantu peserta didik menguasai tujuan belajar yang spesifik. Salah satu karakteristik modul yaitu self instruction. Dengan self instruction maka memungkinkan peserta didik untuk dapat belajar secara mandiri dan tidak bergantung pada pihak lain. Berdasarkan karakteristik tersebut, maka modul merupakan salah satu media yang tepat digunakan dalam pembelajaran IPA yang diajarkan dengan metode discovery learning.

Besarnya peran media pembelajaran dalam pembelajaran IPA, maka peneliti bermaksud untuk mengembangkan modul praktikum IPA. Dengan modul ini, diharapkan siswa dapat mempelajari IPA secara mandiri. Modul yang dikembangkan adalah modul yang membantu siswa melakukan kegiatan-kegiatan percobaan sesuai dengan kompetensi yang ada 
di kelas V Sekolah Dasar. Oleh karena itu, judul penelitian ini adalah "Pengembangan Modul Praktikum Dilan (Discovery Learning) untuk pembelajaran Sains di Kelas V SD”.

\section{B. Landasan Teori}

\section{Pendekatan Discovery Learning}

Howe dalam Azizah \& Winarti, P (2016) mengemukakan Discovery Learning adalah suatu metode pengajaran yang memberikan memerlukan lebih banyak otonomi murid atau kebebasan murid dibandingkan dengan pengajaran langsung. Metode Discovery Learning atau belajar menemukan merupakan metode pembelajaran yang menciptakan situasi belajar yang melibatkan siswa belajar secara aktif dan mandiri dalam menemukan suatu konsep atau teori, pemahaman, dan pemecahan masalah. Proses penemuan tersebut membutuhkan guru sebagai fasilitator dan pembimbing. Banyaknya bantuan yang diberikan guru tidak mempengaruhi siswa untuk melakukan penemuan sendiri. Belajar menemukan (discovery learning) lebih dari pengalaman-pengalaman langsung, tetapi yang paling penting adalah pengalaman berpikir. Melalui diskusi terbimbing dan metode-metode lain, anak dibawa kepada aktivitas dengan membandingkan (comparing), mencari pola-pola, penarikan kesimpulan, dan membuat penjelasan-penjelasan tentang percobaan.

Selanjutnya Carin, A. (1993) menyatakan bahwa "Discovery"adalah suatu proses mental dimana anak atau individu mengasimilasi konsep dan prinsip, atau dapat dinyatakan "Discovery" terjadi apabila siswa terutama terlibat dalam menggunakan proses mental untuk menemukan beberapa konsep atau prinsip. Proses mental tersebut ialah mengamati, menggolong-golongkan, membuat dugaan, menjelaskan, mengukur, menarik kesimpulan, dan sebagainya.

Dari beberapa pengertian di atas dapat disimpulkan bahwa pendekatan discovery learning adalah proses mental dimana anak atau siswa dapat mengasimilasi konsep atau prinsip secara aktif dan mandiri dalam menemukan suatu konsep atau teori, pemahaman, dan pemecahan masalah melalui keterampilan sains seperti mengamati, menggolong-golongkan, membuat dugaan, menjelaskan, mengukur, menarik kesimpulan, dan sebagainya.

Hasil penelitian yang dilakukan oleh Carl Rogers dalam Carin, A (1993) menunjukan bahwa keuntungan siswa yang mempelajari sains dengan menggunakan pendekatan Discovery Learning yaitu (1) siswa dapat menemukan ilmu yang baru dan menarik, (2) siswa berharap memiliki lebih banyak ilmu, (3) siswa merasa sains sangat berguna dalam kehidupan sehari-hari, (4) siswa memiliki perasaan senang karena sukses atau berhasil 
menemukan pengetahuan baru, dan (5) siswa memiliki pandangan yang lebih positif tentang sains dan para ilmuwan.

\section{Modul Berpendekatan Discovery Learning}

Menurut Surahman (2012:40) modul adalah satuan program pembelajaran terkecil yang dapat dipelajari oleh peserta didik secara perseorangan (self instructional), setelah peserta menyelesikan satu satuan dalam modul, selanjutnya peserta dapat melangkah maju dan mempelajari satuan modul berikutnya.

Dari pendapat di atas dapat disimpulkan bahwa modul adalah sebuah media pembelajaran yang disusun secara sistematis dengan bahasa yang mudah dipahami oleh peserta didik sesuai tingkat pengetahuan dan usia mereka agar dapat belajar sendiri dengan bantuan atau bimbingan yang minimal dari guru.

Modul praktikum IPA berpendekatan Discovery Learning adalah media pembelajaran yang dapat dipelajari secara mandiri berisi tujuan pembelajaran, ringkasan materi dan kegiatan praktikum untuk membuktikan fenomena alam. Kegiatan praktikum disertai dengan beberapa pertanyaan yang menuntut peserta didik melakukan keterampilan proses sains yaitu mengamati, mengukur, komunikasi, mengklasifikasikan, prediksi, dan interferensi/hipotesis. Melalui kegiatan praktikum dan proses mencari tahu jawaban atas pertanyaan yang disajikan, siswa dapat membuat kesimpulan sendiri atas materi yang mereka pelajari tersebut.

Tujuan penyusunan modul berpendekatan Discovery Learning yang diadopsi dari Andi Prastowo (2013) antara lain:

1) Agar peserta didik dapat belajar secara mandiri tanpa atau dengan bimbingan pendidik. Hal ini sesuai dengan karakteristk pendekatan Discovery Learning.

2) Agar peran pendidik tidak terlalu dominan dan otoriter dalam kegiatan pembelajaran sehingga peserta didik dapat menemukan pengetahuannya sendiri.

3) Melatih kejujuran peserta didik. Dengan tujuan memperoleh pengetahuan baru atau membuktikan fenoma yang terjadi maka langkah kerja dalam kegitan praktikum dibuat secara sistematis sehingga peserta didik melakukan kegiatan praktikum sesuai dengan perintah yang ada pada modul.

4) Mengakomodasi berbagai tingkat dan kecepatan belajar peserta didik. Peserta didik yang telah dapat membuat kesimpulannya sendiri dapat melanjutkan ke kegiatan praktikum selanjutnya.

5) Agar peserta didik mampu mengukur sendiri tingkat penguasaan materi yang telah dipelajari. Pada bagian akhir modul dilengkapi dengan evaluasi terkait dengan materi yang telah dipelajari lewat kegiatan praktikum. 


\section{METODE}

\section{Jenis Penelitian}

Penelitian ini menggunakan model penelitian Borg and Gall yang meliputi sepuluh kegiatan, yaitu: (1) studi pendahuluan, (2) perencanaan penelitian, (3) pengembangan produk awal, (4) uji lapangan terbatas, (5) revisi hasil uji lapangan terbatas, (6) uji lapangan lebih luas, (7) revisi hasil uji lapangan lebih luas, (8) uji kelayakan, (9) revisi hasil uji kelayakan, (10) desiminasi dan sosialisasi produk akhir, (Sani, Manurung, Suswanto, \& Sudiran, 2018)

\section{Subjek dan Lokasi Penelitian}

Subjek pengembangan dibagi ke dalam 2 kelompok yaitu subjek ujicoba kecil dan subjek ujicoba besar. Subjek ujicoba kecil adalah ujicoba awal produk yang melibatkan 5 siswa. Subjek ujicoba besar yaitu ujicoba akhir produk dengan melibatkan sebanyak 113 siswa dari 3 SD yang berada di Kabupaten Semarang.

Lokasi penelitian ini berbeda-beda sesuai dengan jenis kegiatannya. Pada saat ujicoba produk kelompok kecil dilaksanakan di SDN kalirejo 02 Kecamatan Ungaran Timur Kabupaten Semarang. Ujicoba produk lapangan atau kelompok besar dilaksanakan dibeberapa tempat yaitu di SDN Kalirejo 02 Kecamatan Ungaran Timur, SDN Langensari 03 dan SDN Bergas Lor 01 Kecamatan Bergas.

\section{Data dan Sumber Data}

Data dan sumber data yang digunakan untuk pengembangan data, yaitu (1) data penilaian ahli, (2) data hasil ujicoba kelompok kecil dan (3) data hasil ujicoba kelompok besar.

1. Data Penilaian Ahli

Data penilaian ahli digunakan untuk mengetahui kevalidan dari modul yang dikembangkan. Data ini berupa pernyataan tentang validitas bahan ajar oleh para ahli. Sumber data adalah beberapa orang ahli yang berkompeten dalam bidang pengembangan bahan ajar.

2. Data Hasil Ujicoba Kelompok Kecil

Data hasil ujicoba kelompok kecil digunakan untuk menguji kepraktisan dari modul yang dikembangkan. Data ini berupa hasil observasi pelaksanaan praktikum pembelajaran IPA dengan menggunakan modul Praktikum berbasis discovery learning pembelajaran IPA. Sumber data adalah hasil observasi pelaksanaan praktikum pembelajaran IPA pada kelompok kecil.

3. Data Hasil Ujicoba Kelompok Besar 
Data hasil ujicoba kelompok besar digunakan untuk menguji keefektifan dari modul yang dikembangkan. Data ini berupa hasil pelaksanaan praktikum pembelajaran IPA dengan menggunakan Modul Praktikum Dilan (Discovery Learning) untuk pembelajaran Sains di Kelas V SD pada kelompok besar. Sumber data adalah hasil tes tertulis sebelum dan setelah menggunakan Modul Praktikum Dilan (Discovery Learning) untuk pembelajaran Sains di Kelas V SD saat pelaksanaan praktikum pembelajaran IPA pada kelompok besar.

\section{Instrumen dan Teknik Pengumpulan Data}

Ada beberapa instrumen yang digunakan dalam penelitian ini. Instrumen tersebut seperti kuesioner, angket dan tes.

\section{Teknik Analisis Data}

Terdapat tiga langkah dalam menganalisis data hasil penelitian ini. Tiga langkah tersebut yaitu analisis validitas modul, analisis kepraktisan modul, dan analisis keefektifan modul.

\section{HASIL DAN PEMBAHASAN}

\section{Studi Pendahuluan}

Tahap awal dalam penelitian ini adalah dengan melakukan studi lapangan dan studi literasi. Tahap studi lapangan dilakukan dengan wawancara guru-guru di beberapa sekolah dasar Kabupaten Semarang seperti SDN Leyangan Kecamatan Ungaran Timur, SDN Langensari 03 Kecamatan Bergas, SDN Kalirejo 02 diperoleh bahwa kurangnya media pembelajaran seperti alat peraga dan modul praktikum dalam pelajaran IPA. Hasil dari studi lapangan yang dilakukan, diketahui bahwa pelaksanaan pembelajaran IPA di SD terdapat permasalahan terhadap kegiatan praktikum, diantaranya: a) guru-guru hanya mengandalkan buku paket dan LKS (Lembar Kerja Siswa) dalam pembelajaran IPA, b) guru lebih banyak mendrill tanpa menanamkan konsep IPA kepada siswa, c) minimnya kegiatan praktikum yang dilakukan oleh guru-guru tersebut dikarenakan oleh kurangnya alat peraga dan media pembelajaran IPA yang dimiliki oleh sekolah. Dari temuan yang ada, langkah selanjutnya peneliti melakukan studi literasi/pustaka. Peneliti melakukan analisis kurikulum tentang Kompetensi Inti (KI) dan Kompetensi Dasar (KD) Pembelajaran IPA SD sesuai dengan kurikulum yang berlaku, yaitu kurikulum 2013.

\section{Perencanaan penelitian dan pengembangan produk awal}

Pada tahap ini, peneliti membuat draf atau desain modul Praktikum berbasis discovery learning IPA SD. Desain yang dibuat dengan menyesuaikan isi modul, karakteristik anak SD, serta materi pembelajaran IPA. 
Setelah draf jadi, langkah selanjutnya adalah menyusun modul. Modul yang dibuat yaitu modul Praktikum berbasis discovery learning IPA Kelas V SD, yang diberi nama "Modul Praktikum DILAN (Discovery Learning) berisi materi kalor dan perpindahannya, Pengaruh Kalor terhadap Suhu Wujud Benda, Siklus Air dan Dampaknya, dan Penggolongan Materi.

Modul tersebut memiliki unsur-unsur modul yaitu (1) Petunjuk Penggunaan modul; (2) Kompetensi Inti, Kompetensi Dasar, Tujuan Pembelajaran; (3) Peta Konsep; (4) Rangkuman; (5) Tes Formatif; (6) Pedoman Penskoran Tes Formatif; (7) Tindak Lanjut; (8) Kunci Jawaban; dan (9) Glosarium. Selain unsur-unsur di atas, juga ditambah dengan "Info Tambahan" yang dimuat dalam kotak "Info Sains" untuk menambah wawasan pembaca.

Modul yang dikembangkan dilengkapi dengan gambar-gambar beserta penjelasannya. Hal ini bertujuan untuk menarik perhatian siswa dan memperjelas materi yang mereka pelajari.

\section{Uji Lapangan Terbatas}

Sebelum produk diujicobakan dalam kelompok kecil/terbatas, modul yang dikembangkan harus valid atau sangat valid. Untuk mendapatkan kriteria tersebut, peneliti melakukan uji lapangan terbatas dengan memvalidasi modul kepada ahli yaitu (1) Bapak Ikhlasul Ardi Nugroho, S.Pd.Si., M.Pd, Dosen IPA PGSD dari Universitas Negeri Yogyakarta dan (2) Bapak Satya Eko Atmojo, M.Pd, Dosen IPA PGSD dari Universitas PGRI Yogyakarta.

Data hasil validasi tentang Modul Praktikum Dilan (Discovery Learning) untuk pembelajaran Sains di Kelas V SD dianalisis secara deskriptif. Pengembangan Bahan Ajar dikatakan baik jika rata-rata dari seluruh indikator minimal dalam kategori baik.

Pedoman penilaian dan teknik penskoran selengkapnya terdapat pada lembar validasi. Rata-rata skor dari masing-masing perangkat pembelajaran dihitung dengan cara sebagai berikut.

$$
\text { Rata }- \text { rata skor }=\frac{\text { Total skor }}{\text { Jumlah Deskriptor }}
$$

Hasil penelitian di atas kemudian dikonversi ke penelitian kualitatif. Berikut kriteria penilaian kualitatif.

Tabel 1. Kriteria penilaian kualitatif

\begin{tabular}{|c|c|}
\hline Rentang & Data Kualitatif \\
\hline$X>54,6$ & Sangat Valid \\
\hline $44,2<X \leq 54,6$ & Valid \\
\hline $33,8<X \leq 44,2$ & Cukup Valid \\
\hline $23,4<X \leq 33,8$ & Kurang Valid \\
\hline
\end{tabular}




\begin{tabular}{|l|l|}
\hline $\mathrm{X} \leq 23,4$ & Sangat kurang Valid \\
\hline
\end{tabular}

Menurut Daryanto (2018), penilaian validasi modul terdiri dari isi materi dan penyajian pembelajaran. Berdasarkan hasil validasi dari para ahli didapatkan nilai berikut.

Tabel 2. Hasil Validasi Ahli

\begin{tabular}{|c|c|c|c|}
\hline Ahli & Validasi 1 & Validasi 2 & Kriteria \\
\hline Ahli 1 & 53 & 61 & - \\
\hline Ahli 2 & 51 & 62 & - \\
\hline Rata-rata & 52 & 61,5 & Sangat Valid \\
\hline
\end{tabular}

Berdasarkan Tabel 2 di atas, digambarkan bahwa nilai rata-rata validasi modul pertama kali yaitu 52 dengan kriteria valid. Melalui komentar dan saran dari para Ahli saat validasi pertama, maka modul direvisi. Setelah modul direvisi, selanjutnya para Ahli kembali melakukan penilaian. Hasil penilaian pada validasi kedua yaitu sebesar 61,5. Penilaian ini masuk kriteria sangat valid, sehingga diputuskan untuk melangkah pada tahap selanjutnya.

Grafik perolehan nilai dari hasil validasi tahap pertama dan kedua disajikan dalam gambar berikut ini.

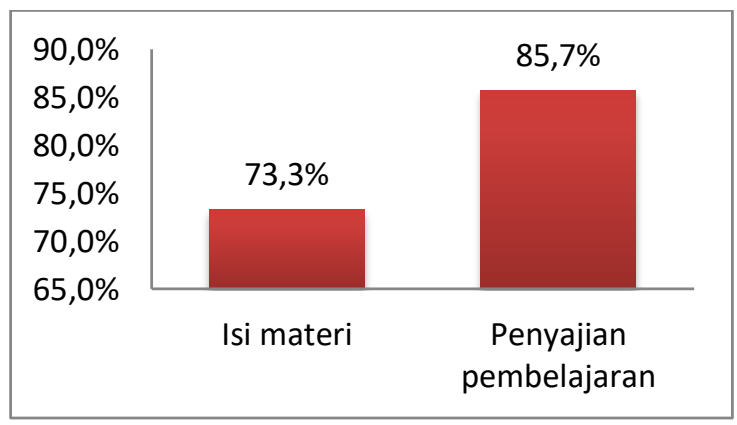

Gambar 1. Grafik penilaian validitas 1 modul

Grafik di atas menggambarkan bahwa isi materi modul Praktikum Dilan memperoleh presentasi $73,3 \%$. Sedangkan penyajian pembelajarannya sebesar $85,7 \%$. 


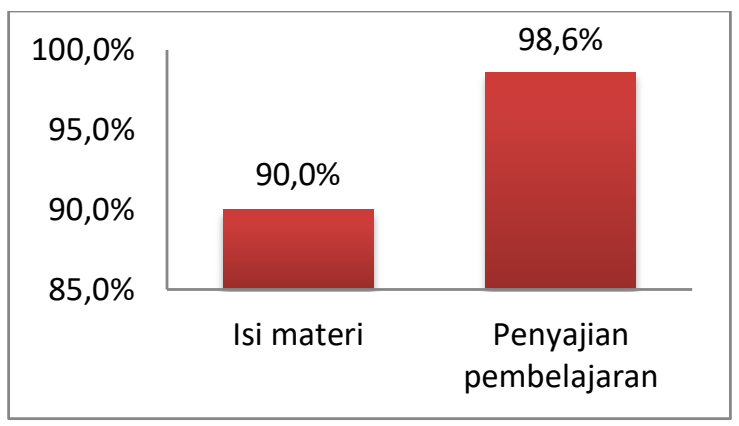

Gambar 2. Grafik penilaian validitas 2 modul

Setelah dilakukan revisi atas saran dan komentar para Ahli, maka diperoleh hasil validasi sebesar $90 \%$ untuk isi materi dan $98,6 \%$ untuk penyajian pembelajaran.

\section{Perbaikan Desain}

Dari hasil validasi para ahli terdapat beberapa masukan yang harus dipertimbangkan. Masukan tersebut yaitu: (1) memberikan penjelasan dengan contoh nyata dalam kegiatan pembelajaran, dan (2) memunculkan kegiatan yang mengandung discovery learning dengan menukar posisi bagian dalam modul yaitu kegiatan percobaan terlebih dahulu kemudian diikuti dengan penjelasan materi.

Selanjutnya dilakukan perbaikan modul berdasarkan arahan dari para ahli. Setelah melakukan perbaikan, modul dinyatakan sangat valid dan siap untuk uji kepraktisan pada kelompok kecil.

\section{Uji Lapangan}

Modul hasil pengembangan yang telah valid kemudian diuji lapangan pada kelompok terbatas yang berjumlah 15 orang. Subjek uji lapangan ini adalah siswa kelas V dari SDN Kalirejo 02 Kecamatan Ungaran Timur, SDN Ungaran 01, dan SDN Sidomulyo 03 Kabupaten Semarang masing-masing berjumlah 5 siswa. Uji lapangan ini bertujuan untuk mengetahui kepraktisan Modul Praktikum Dilan (Discovery Learning) untuk pembelajaran Sains di Kelas V SD.

Modul Praktikum Dilan dikatakan praktis jika mendapatkan respon positif dari penggunanya. Data kepraktisan modul didapatkan dari data angket yang telah diisi oleh siswa setelah mereka selesai melaksanakan praktikum dengan menggunakan Modul Praktikum Dilan (Discovery Learning) untuk pembelajaran Sains di Kelas V SD. Modul ini dinyatakan praktis jika berada pada kriteria minimal praktis. Rata-rata skor hasil angket siswa dihitung dengan menggunakan formula berikut:

$$
\text { Rata }- \text { rata skor }=\frac{\text { Total skor }}{\text { Jumlah Deskriptor }}
$$


Hasil dari rata-rata skor di atas kemudian ditentukan kriteria kepraktisannya dengan mengacu pada tabel berikut:

Tabel 3. Kriteria penilaian kepraktisan

\begin{tabular}{|c|l|}
\hline Rentang & \multicolumn{1}{|c|}{ Data Kualitatif } \\
\hline$X>63$ & Sangat Praktis \\
\hline $51<X \leq 63$ & Praktis \\
\hline $39<X \leq 51$ & Cukup Praktis \\
\hline $27<X \leq 39$ & Kurang Praktis \\
\hline$X \leq 27$ & Sangat kurang Praktis \\
\hline
\end{tabular}

Aspek penilaian dalam uji kepraktisan yaitu (a) efektif, (b) interaktif, (c) menarik, (d) efisien, dan (e) kreatif. Jumlah pernyataan dari kuesioner kepraktisan sebanyak 15 butir. Dari analisis data diperoleh nilai sebesar 66,27 atau sangat praktis. Sehingga dapat disimpulkan bahwa modul Praktikum Dilan (discovery learning) dapat diuji pada pemakaian lapangan karena telah memenuhi syarat yaitu berkriteria sangat praktis. Secara rinci, perolehan nilai kepraktisan modul berdasarkan aspek penilaiannya digambarkan sebagai berikut.

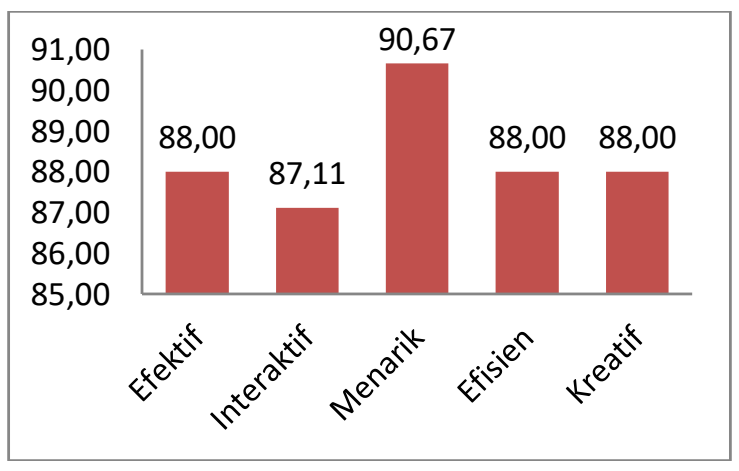

Gambar 3. Grafik penilaian kepraktisan modul

Berdasarkan grafik penilaian kepraktisan modul di atas, diperoleh nilai untuk aspek efektif sebesar 88,00, aspek interaktif sebesar 87,11, aspek menarik sebesar 96,67, aspek efisien sebesar 88,00 dan aspek kreatif sebesar 88,00.

\section{Revisi Hasil Uji Lapangan}

Setelah modul diuji lapangan pada kelompok terbatas maka dapat diketahui kekurangan dan kelebihan Modul Praktikum Dilan (Discovery Learning) untuk pembelajaran Sains di Kelas V SD. Langkah selanjutnya adalah melakukan revisi terhadap kekurangan modul. Tetapi hasil uji lapangan dinyatakan bahwa Modul Praktikum Dilan (Discovery Learning) untuk pembelajaran Sains di Kelas V SD masuk kriteria sangat praktis sehingga dapat digunakan tanpa adanya revisi. 


\section{Ujicoba Pemakaian Lapangan}

Kegiatan ini dilakukan untuk mengetahui keefektifan dari Modul Praktikum Dilan (Discovery Learning) untuk pembelajaran Sains di Kelas V SD yang dikembangkan. Uji pemakaian lapangan dilakukan dibeberapa sekolah yaitu di SDN Kalirejo 02 Kecamatan Ungaran Timur, SDN Langensari 03 dan SDN Bergas Lor 01 Kecamatan Bergas. Jumlah sampel pada ujicoba lapangan sebanyak 113 siswa yang terdiri dari kelas V SD.

Pada saat uji pemakaian lapangan, siswa diberikan tes untuk mengukur tingkat keefektifan dari modul yang digunakan. Tes ini diberikan sebelum dan setelah siswa melakukan kegiatan praktikum dengan menggunakan modul Praktikum berbasis discovery learning IPA SD.

Teknik analisis data yang digunakan untuk menganalisis hasil uji pemakaian lapangan yaitu teknik analisis Uji Gain ternormalisasi.

Hake dalam Rostina Sundayana (2015), mengembangkan rumus Gain ternormalisasi sebagai berikut:

Gain ternormalisasi $(g):=\frac{\text { skor postes }- \text { skor pretes }}{\text { skor ideal }- \text { skor pretes }}$

Adapun kriteria tingkat capain Uji Gain yaitu:

\section{Tabel 4 Kriteria n-Gain}

\begin{tabular}{|c|c|}
\hline Nilai & Kriteria \\
\hline $0,00 \leq \mathrm{N} \leq 0,30$ & Rendah \\
\hline $0,30 \leq \mathrm{N} \leq 0,70$ & Sedang \\
\hline $0,70 \leq \mathrm{N} \leq 1,00$ & Tinggi \\
\hline
\end{tabular}

Rangkuman hasil ujicoba lapangan terkait penggunaan modul tersebut sebagai berikut:

Tabel 5 Rekapitulasi hasil uji pemakaian lapangan

\begin{tabular}{|c|c|c|c|}
\hline $\begin{array}{c}\text { Rata- } \\
\text { rata } \\
\text { pretes }\end{array}$ & $\begin{array}{c}\text { Rata- } \\
\text { rata } \\
\text { postes }\end{array}$ & $\begin{array}{c}\text { n- } \\
\text { gain }\end{array}$ & kategori \\
\hline 60,0 & 88,4 & 0,72 & Tinggi \\
\hline
\end{tabular}

Dari tabel di atas, diperoleh nilai rata-rata pretes sebesar 60,0 dan rata postes sebesar 88,4. Sesuai dengan rumus N-Gain yang dikemukakan sebelumnya, maka didapatkan nilai n-gian sebesar 0,72. Berdasarkan tabel kriteria n-Gain, maka Modul Praktikum Dilan (Discovery 
Learning) untuk pembelajaran Sains di Kelas V SD berada pada kategori tinggi, sehingga dapat disimpulkan bahwa modul ini efektif digunakan dalam Praktikum IPA SD.

\section{Revisi Produk Akhir}

Setelah modul melewati uji pemakaian lapangan, maka Modul Praktikum Dilan (Discovery Learning) untuk pembelajaran Sains di Kelas V SD dapat diketahui nilai keefektifannya. Langkah selanjutnya melakukan revisi terhadap modul tersebut. Hasil dari ujicoba pemakaian lapangan, didapatkan bahwa Modul Praktikum Dilan (Discovery Learning) untuk pembelajaran Sains di Kelas V SD telah efektif sehingga dapat digunakan tanpa revisi.

Pegembangan modul melalui tahapan penelitian R\&D yang telah dilakukan menghasilkan Modul Praktikum Dilan (Discovery Learning) untuk pembelajaran Sains di Kelas V SD yang valid, praktis, dan efektif. Artinya modul ini dapat digunakan oleh guru dan siswa sekolah dasar khususnya kelas V dalam pembelajaran IPA. Modul ini membantu guru dan siswa dalam melakukan pembelajaran yang kompetensinya melakukan percobaan.

Melalui Modul Praktikum Dilan (Discovery Learning) untuk pembelajaran Sains di Kelas V SD, pembelajaran akan bermakna karena siswa menemukan sendiri pengetahuan dari percobaan yang telah dilakukan. Dengan pendekatan Discovery Learning, siswa menjadi aktif dan mandiri dalam melakukan percobaan yang pada akhirnya membuat siswa dapat menemukan suatu konsep, memahami materi serta dapat memecahkan permasalahan. Siswa merasa senang karena telah berhasil menemukan pengetahuan baru dan memecahkan permasalahan yang diberikan oleh guru. Selain itu, siswa tertarik mempelajari sains karena mereka beranggapan mempelajari sains sama dengan mempelajari alam sekitar. Permasalahan-permasalahan dalam kehidupan sehari-hari dapat dipecahkan dengan ilmu sains. Hal ini sesuai dengan hasil penelitian yang dilakukan oleh Carl Rogers. Menurut Carl Rogers, pendekatan discovery learning membuat siswa tertarik mempelajari sains, sains berguna dalam kehidupan sehari-hari, merasa sukses karena dapat menemukan pengetahuan baru serta memiliki pandangan positif pada sains dan para ilmuwan.

\section{E. SIMPULAN DAN SARAN}

Berdasarkan hasil penelitian yang telah dilakukan, maka dapat disimpulkan:

1. Modul Praktikum Dilan (Discovery Learning) untuk pembelajaran Sains di Kelas V SD yang dikembangkan telah memenuhi kriteria valid. Hal ini dibuktikan dengan hasil ratarata validasi ahli sebesar 61,5 dengan kriteria valid. 
2. Modul Praktikum Dilan (Discovery Learning) untuk pembelajaran Sains di Kelas V SD yang dikembangkan telah memenuhi kriteria praktis. Hal ini dibuktikan dengan hasil kuesioner dari ujicoba kelompok kecil. Perolehan nilai sebesar 63,80 dengan kriteria sangat praktis.

3. Modul Praktikum Dilan (Discovery Learning) untuk pembelajaran Sains di Kelas V SD telah memenuhi kriteria efektif. Hal ini dibuktikan dengan hasil nilai N-Gain. Berdasarkan analisis N-Gain diperoleh bahwa nilai N-Gain dengan kategori tinggi sebanyak 0,72. Hal ini menandakan bahwa Modul Praktikum Dilan (Discovery Learning) untuk pembelajaran Sains di Kelas V SD efektif digunakan dalam kegiatan praktikum Pembelajaran IPA di sekolah dasar.

Adapun saran yang direkomendasikan oleh peneliti adalah sebagai berikut:

1. Sebaiknya dilakukan ujicoba dengan sampel yang lebih luas lagi agar diketahui gambaran tingkat keefektifan Modul Praktikum berbasis discovery learning IPA SD dalam pembelajaran IPA.

2. Perlu adanya penelitian lanjutan untuk memperbaiki modul, misalnya dalam bentuk eksperimen pada sekolah lainnya.

\section{PERSANTUNAN}

Ucapan terima kasih kami sampaikan kepada Kemenristekdikti atas pendanaan yang diberikan kepada kami dalam melaksanakan penelitian ini. Penilitian ini merupakan Penelitian Dosen Pemula (PDP) dengan nomor Kontrak 005b/A.II/II/2018 Tahun Anggaran 2018 .

\section{F. PUSTAKA ACUAN}

Azizah, \& Winarti, P. (2016). Pengaruh Guided Discovery terhadap Hasil Belajar IPA Siswa Kelas IV SDN Gedanganak 01 Kecamatan Ungaran Timur Kabupaten Semarang. Jurnal Profesi Pendidikan Dasar , 3 (1), 1-10.

Carin, A. A. (1993). Teaching Science Through Discovery. New York: Macmillan Publishing Company.

Collette, A. T., \& Chiappetta, E. L. (1994). Science Instruction in the Middle and Secondary Schools. New York: Macmillan Publishing.

Daryanto. (2013). Menyusun Modul, Bahan ajar untuk persiapan guru dan mengajar. Yogyakarta: Gava Media. 
Mulyasa. (2010). Menjadi Guru Profesional (Menciptakan Pembelajaran Kreatif dan Menyenangkan). Bandung: Rosdakarya.

Pemprov. (2013). Renstra Dinas Pendidikan Provinsi Jawa Tengah Tahun 2013-2018. Semarang: Dinas Pendidikan Jawa Tengah.

Prastowo, A. (2014). Pengembangan Bahan Ajar Tematik. Jakarta: Kencana Prenada Media Group.

Sani, R. A., Manurung, S. R., Suswanto, H., \& Sudiran. (2018). Penelitian Pendidikan. Tangerang: Tira Smart.

Sundayana, R. (2015). Statistika Penelitian Pendidikan. Bandung: Alfabeta.

Surahman. (2012). Media Pembelajaran dalam Proses Perkuliahan. Semarang: Unnes. 